\title{
ACTIVITY OF AN $\alpha$-L-RHAMNOSIDASE PRODUCED BY Aspergillus niger DURING SOLID STATE FERMENTATION OF COFFEE PULP WASTES
}

\author{
Kahar Muzakhar*1, Rudju Winarsa ${ }^{2}$
}

Received : March 28, 2019
Accepted : May 03, 2019
DOI: 10.15575/biodjati.v4i1.4411

${ }^{1,2}$ Department of Biology, Faculty Mathematic and Natural Sciences, Universitas Jember, Jl. Kalimantan, Jember, Indonesia 68121

e-mail:

${ }^{*}$ kaharmzk@unej.ac.id

${ }^{2}$ rudjuwin@yahoo.com

*Corresponding author
Abstract. An $\alpha$-L-Rhamnosidase released by Aspergillus niger during solid-state fermentation (SSF) using coffee pulp (CP) wastes media has been investigated. The activity of $\alpha$-L-Rhamnosidase based on reducing sugar production against $2 \%$ CP alkali extract substrate in $50 \mathrm{mM}$ acetate buffer $\mathrm{pH}$ 5. The maximum activity of $\alpha$-L-Rhamnosidase was obtained in sixth-day SSF with reducing sugar production of $13 \mu \mathrm{g} / \mathrm{mL}$. The enzyme is actively hydrolyzed $0.1 \% \mathrm{p}$-nitrophenyl- $\alpha$-L-rhamnopyranoside (PNP-Rha) to $95 \%$ from initial concentration. Purification using DEAE-Toyopearl 650M increased hydrolysis activity ten times against the substrate, reaching $134 \mu \mathrm{g} / \mathrm{mL}$ of reducing sugar. Optimum enzyme activity at $\mathrm{pH} 4.5$ and $50^{\circ} \mathrm{C}$, while stable at $\mathrm{pH}$ and temperature in a $\mathrm{pH}$ range of 3.5-7 and below $50^{\circ} \mathrm{C}$.

Keywords: $\alpha$-L-Rhamnosidase, Aspergillus niger, coffee pulp wastes, solid-state fermentation

\section{Citation}

Muzakhar, K. \& Winarsa, R. (2019). Activity of an $\alpha$-L-Rhamnosidase by Aspergillus niger During Solid State Fermentation of Coffee Pulp Wastes. Jurnal Biodjati, 4(1), 105-111

\section{INTRODUCTION}

An $\alpha$-L-Rhamnosidase is an enzyme that can specifically release terminal $\alpha$-L-Rhamnose from several flavonoids glycosides, glycolipids and some natural products (Caldini et al., 1994; Vila-Real, et al., 2011; Yadav, et al., 2011; Yadav, 2018). This enzyme is widely distributed in nature and has been successfully purified from animal tissue, plants and several species microorganisms such as yeast, fungi and bacteria (Gastón et al., 2007; Yadav et al., 2010; Ding et al., 2017). This enzyme has been widely used in several industrial applications as a catalyst (Habelt \& Pittner, 1983; Bokkenheuser et al., 1987; Caldini et al., 1994; Wang et al., 2005; Birgisson et al., 2007). The application of enzymes in the bioconversion process is the veracious strategy because it does not harm either have no negative impact to the environment and further its stability of the biodiversity in ecosystem function will always be maintained (Prakasham et al., 2007; Muzakhar et al., 2015; Muzakhar et al., 2017). However, to produce enzyme still requires a quite costly process including the materials either purification process. Utilization of coffee pulp (CP) waste material to produce this enzyme is a breakthrough that can be considered because of its huge availability in the environment. Preliminary investigation also revealed that this Aspergillus niger easily grow in coffee pulp as carbon and nitrogen without any nutrient added and much black spores appear after 3-4 days incubated at $30^{\circ} \mathrm{C}$. Based on these reasons, the investigation of microbial utilization of $\mathrm{CP}$ to produce $\alpha$-L-Rhamnosidase was reported. 


\section{JURNAL BIDDJATI}

http://journal.uinsgd.ac.id/index.php/biodjati

\section{MATERIALS AND METHODS}

The coffee pulp was collected from a coffee plantation at mountain of Ijen mountain area of Bondowoso district. Anion exchanger chromatography DEAE Toyopearl $650 \mathrm{M}$ was purchased from TOSOH Corp. and all chemical substances were obtained from Sigma.

\section{Cultivation of Aspergillus niger and Opti- mization of Crude $\alpha$-L-Rhamnosidase Pro- duction}

The stock culture of Aspergillus niger was preserved in PDA medium every two weeks and used for producing crude $\alpha$-L-Rhamnosidase. To optimize $\alpha$-L-Rhamnosidase production under solid state fermentation (SSF), $50 \mathrm{~g}$ of sterilized CP in a one liter Erlenmeyer flask was inoculated with three loops full of $A$. niger and incubated at $30^{\circ} \mathrm{C}$ for 5 days. The crude enzyme was daily harvested and measured for the activity. To harvest the enzyme was conducted by adding 500 $\mathrm{mL}$ of distilled water containing $1 \% \mathrm{NaCl}$ and $0.1 \%$ toluene $(\mathrm{v} / \mathrm{v})$ and shaking at $120 \mathrm{rpm}$ and $30^{\circ} \mathrm{C}$ for 9 hours. The suspension was filtered using glass filter, centrifuged to recover the supernatant, dialyzed through a column ( 5 x $25 \mathrm{~cm}$ ) DEAE-cellulose against $20 \mathrm{mM}$ acetate buffer $\mathrm{pH} 5$ and used as a source enzyme for next analysis. Under the same procedure, the large quantity of crude $\alpha$-L-Rhamnosidase production, SSF of $500 \mathrm{~g} \mathrm{CP}$ in 5 L erlenmeyer flask was done.

\section{Preparation of Substrate Coffe Pulp (CP) Alkali Extract and Coffee Bean Arabinoga- lactan}

Five hundred grams of CP powder was suspended in two liters of $10 \% \mathrm{NaOH}$, stirred for 12 hours and filtered. The filtrate was centrifuged at $8000 \mathrm{rpm}$ for 20 minutes, recovered the supernatant and adjusted to $\mathrm{pH} 5$ with acetic acid. The supernatant was made to $50 \%$ ethanol and centrifuged $8000 \mathrm{rpm}$ for $20 \mathrm{~min}$ utes to obtain the pellets and dried under reduced pressure at $50^{\circ} \mathrm{C}$. The dry matter as $\mathrm{CP}$ alkali substrate was about $4.3 \%$ of the starting material.

The arabinogalactan from coffee bean substrate was prepared with the following steps. Fifty grams of coffee bean was extracted with 2 parts of ethanol and benzene solution (1:2), 10 parts water and 20 parts $1.0 \%$ sodium hypochlorite. The residue produced, by extraction, was boiled with 20 parts of water for eight hours, concentrated to an adequate volume (about 200 times from initial concentration) under reduced pressure and mixed with three volumes of cold ethanol about $4^{\circ} \mathrm{C}$. The precipitate obtained was dried by washing with ethanol and ether. Final yield was $2.2 \%$ of the starting material.

\section{Enzyme Assays}

Enzyme activity was determined by measuring the release of reducing sugars by Somogy-Nelson method. One unit of enzyme activity defined as reducing sugar produced at a rate of $1 \mu \mathrm{mol}$ per minute in $1 \mathrm{~mL}$ total volume mixture of enzyme and substrate. The $\alpha$-L-Rhamnosidase activity was also determined by measuring the amount of p-nitrophenol released from the appropriate p-nitrophenyl- $\alpha$-L-rhamnopyranoside.

\section{The Degree of Hydrolysis and Total Sugar Content Analysis}

The degree of hydrolysis was examined in a series of time during incubation of reaction mixture of crude enzyme and $2 \% \mathrm{CP}$ alkali extract substrate at $37^{\circ} \mathrm{C}$. The release of reducing sugars was measured and the degree of hydrolysis was calculated as follows:

Degree of hydrolysis $(\%)=\frac{\text { Total reducing sugar of hydrolyzate }(w / v)}{\text { Total substrate }(w / v)} * 100 \%$ 


\section{JURNAL BIDDJATI}

http://journal.uinsgd.ac.id/index.php/biodjati

The total sugar content of the substrate was measured by the phenol-sulfuric acid method (34).

\section{Purification}

Purification steps were carried out at $25^{\circ} \mathrm{C}$, using $20 \mathrm{mM}$ acetate buffer, $\mathrm{pH} 5$. The initial stages in the purification process, namely the dialysis process using hollow fiber dialysis column $5 \mathrm{Kda}$ against acetate buffer $20 \mathrm{mM} \mathrm{pH} 5$ to remove the remaining sugar and polysaccharides dissolved. The enzyme was then concentrated using $60 \%$ of saturated ammonium sulfate followed by centrifugation at a speed of $12000 \mathrm{rpm}$ to obtain pellets. The pellet was dissolved in small volume and re-dialysis with the same buffer. Subsequently, the dialyzed of crude enzyme was loaded into an on DEAE Toyopearl $650 \mathrm{M}$ column which was pre-equilibrated with the same acetic buffer used. Purification was done by elution $5 \mathrm{~mL}$ per second using a $500 \mathrm{~mL}$ buffer with a gradient concentration of 0 to $0.5 \mathrm{M}$ $\mathrm{NaCl}$, and for each fraction volume was $5 \mathrm{~mL}$. Each fraction was assayed for $\alpha$-L-Rhamnosidase activity against $2 \% \mathrm{CP}$ substrate.

\section{Enzyme Properties}

The effect of $\mathrm{pH}$ and temperature on activity and stability of the enzyme was determined at the $\mathrm{pH}$ range of 2 to 10 and a temperature range of 20 to $70^{\circ} \mathrm{C}$. The effect of $\mathrm{pH}$ on the $\alpha$-L-Rhamnosidase activity was measured after 10 minutes incubation at $37^{\circ} \mathrm{C}$ in $1 \mathrm{~mL}$ $1 \%$ CP substrate. Molecular weights of enzymes were estimated by comparison of their migration rates with those of protein standards in gel filtration Superdex 75 with eluent $1 \mathrm{~mL} /$ min using $20 \mathrm{mM}$ acetate buffer $\mathrm{pH}$ 5. Proteins standard (in Dalton) used, were phosphorylase $(97,400)$, albumin $(66,300)$, aldolase $(42,400)$, carbonic anhydrase $(30,000)$, trypsin inhibitor $(20,100)$ and lysozyme (14.400).

\section{RESULTS AND DISCUSSION}

\section{Optimization of $\boldsymbol{\alpha}$-L- Rhamnosidase}

Extracellular enzyme activity was released by $A$. niger during the SSF process using the CP substrate has been identified as $\alpha$-L-Rhamnosidase. It has been previously known that $A$. niger can produce various types of enzymes to convert their living substrate or medium into biomolecules as material for their metabolism during the growth process. It has been reported that $A$. niger in the SSF process released hydrolase enzymes such as cellulase, xylanase, pectinase and from several groups of lipase enzymes (Hatzinikolaou et al., 1996; Ellaiah et al., 2004; Lúcia et al., 2011; Narasimha et al., 2015; Reddy et al., 2015).

In this study, during the SSF process, showed that $A$. niger was able to grow as indicated by the huge of black spores in the $\mathrm{CP}$ medium. As shown in Figure 1, optimum production of $\alpha$-L-Rhamnosidase occurred on day sixth in room temperature of $30^{\circ} \mathrm{C}$ without additional nutrients into the growth medium. The enzyme hydrolyzed CP and produced reducing sugar $13 \mu \mathrm{g} / \mathrm{mL}$. The activity of $\alpha$-L-Rhamnosidase based on reducing sugar production against $2 \% \mathrm{CP}$ alkali extract substrate in $50 \mathrm{mM}$ acetate buffer $\mathrm{pH}$. This study also calculated that the enzyme maximum hydrolyzed CP medium at 78\% degree of hydrolysis. It can be explained that $A$. niger is able to utilize carbon, nitrogen and mineral sources from the $\mathrm{CP}$ medium.

\section{Purification and Molecular Weight $\alpha-\mathrm{L}-$ Rhamnosidase}

Elucidate the existence of $\alpha$-L-Rhamnosidase, a purification process was done. As shown in Figure 2, fractions 57 to 63 were the active hydrolyzed CP substrate. The active fractions were pooled and re-dialysis against the same buffer to remove remaining $\mathrm{NaCl}$. 


\section{JURNAL BIDDJATI}

http://journal.uinsgd.ac.id/index.php/biodjati

Substrate specificity of $\alpha$-L-Rhamnosidase activity also tested using various substrates such as carboxymethyl-cellulose, arabinogalactan, xylan, pectin and p-nitrophenyl- $\alpha$-L-rhamnopyranoside. As shown in Table 1, when $\mathrm{CP}$ and p-nitrophenyl- $\alpha$-L-rhamnopyranoside substrates were used, $134 \mu \mathrm{g} / \mathrm{mL}$ of reducing sugar and $56 \mu \mathrm{g} / \mathrm{mL}$ of p-nitrophenol was released, with the degree of hydrolysis 78 and $94 \%$. In contrast, no reducing sugars were detected when carboxymethyl-cellulose, arabinogalactan, xylan and pectin substrates were used. This evidence proved that all active fractions only contain $\alpha$-L-Rhamnosidase. Further analysis of enzyme molecular weight as described in the method, the $\alpha$-L-Rhamnosidase has 32,000 Da, approximately.

\section{Optimum and Stability of $\alpha$-L- Rhamnosi- dase on Activity}

The $\alpha$-L-Rhamnosidase exhibited maximum activity at $\mathrm{pH} 4.5$ (Figure 3A) and retained nearly $100 \%$ activity in a $\mathrm{pH}$ range of 3-5.5 after 30 minutes exposure to corresponding $\mathrm{pH}$ values (Figure $3 \mathrm{~B}$ ). $\alpha$-L-Rhamnosidase showed optimum activity at $55^{\circ} \mathrm{C}$ respectively (Figure 3C) and are nearly 100\% stable below $60^{\circ} \mathrm{C}$ after 30 minutes exposure to respective temperatures (Figure 3D).

The successful microbial utilization of CP to produce $\alpha$-L-Rhamnosidase and other extracellular enzymes, is a new strategy in increasing the added value of CP waste. However, research efforts are needed to improve the efficiency of the process.

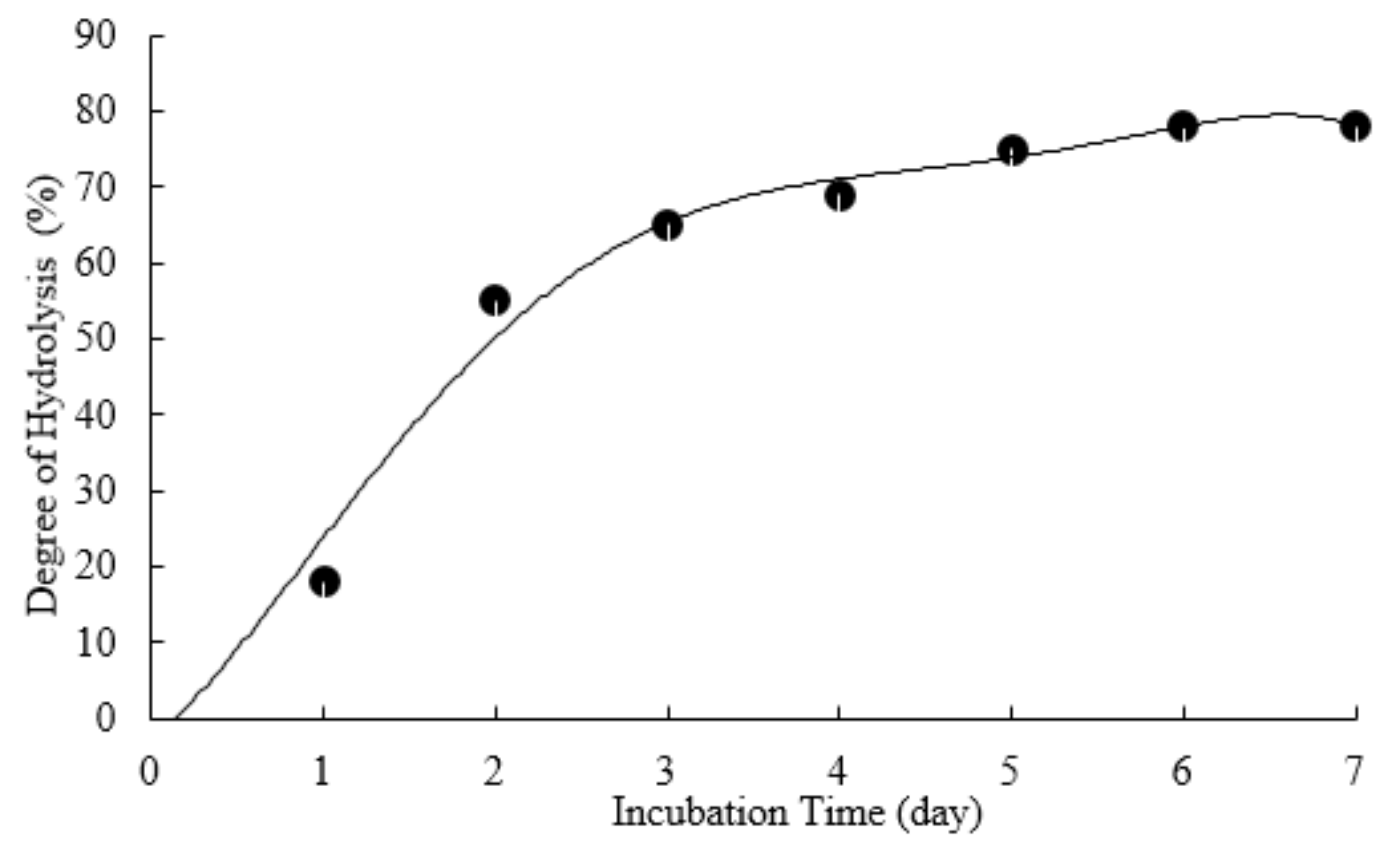

Figure 1. Optimum of $\alpha$-L-Rhamnosidase produced during SSF on CP Substrate after Six days Incubation at $37^{\circ} \mathrm{C}$. 
Jurnal Biodjati 4(1):105-111, May 2019

\section{JURNAL BIDDJATI}

http://journal.uinsgd.ac.id/index.php/biodjati

Table 1. Purified $\alpha$-L-Rhamnosidase activity on various $1 \%$ substrates

\begin{tabular}{|c|c|}
\hline Substrate & $\begin{array}{l}\text { The degree of } \\
\text { Hydrolysis }(\%)\end{array}$ \\
\hline Coffee Pulp & 78 \\
\hline carboxymethyl-cellulose & ND \\
\hline arabinogalactan & ND \\
\hline xylan & ND \\
\hline pectin & ND \\
\hline p-nitrophenyl- $\alpha$-L-rhamnopyranoside* & 94 \\
\hline
\end{tabular}

*) $0.5 \%$ substrate

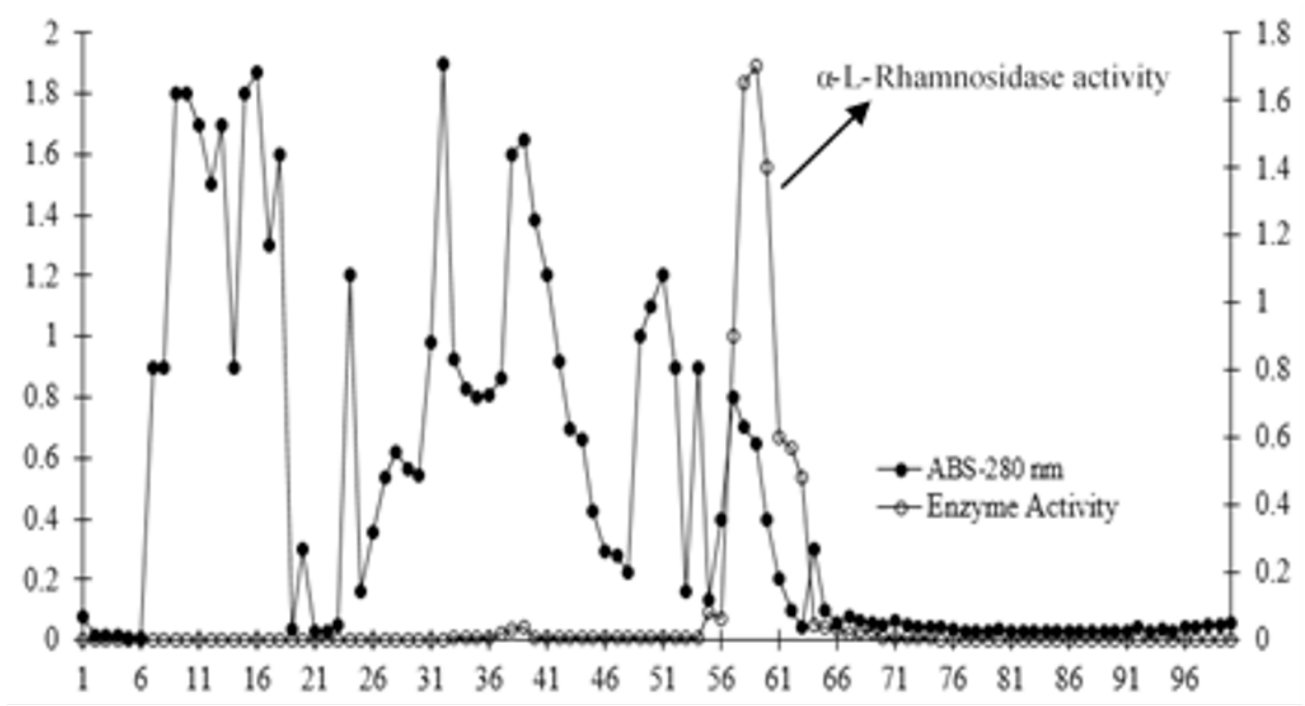

Figure 2. The buffered crude enzyme was loaded an on DEAE Toyopearl 650M column, eluted by using acetate buffer $20 \mathrm{mM}$ pH 5 and gradient $0-0.5 \mathrm{M} \mathrm{NaCl}$. The protein concentration (๑) was monitored at $280 \mathrm{~nm}$, and the $\alpha$-L-Rhamnosidase activity $(\mathrm{O})$ was the checked after 10 minutes incubation of the mixture (100 $\mu$ l crude enzyme in $1 \mathrm{ml}$ of $2 \% \mathrm{CP}$ substrate in the same buffer).
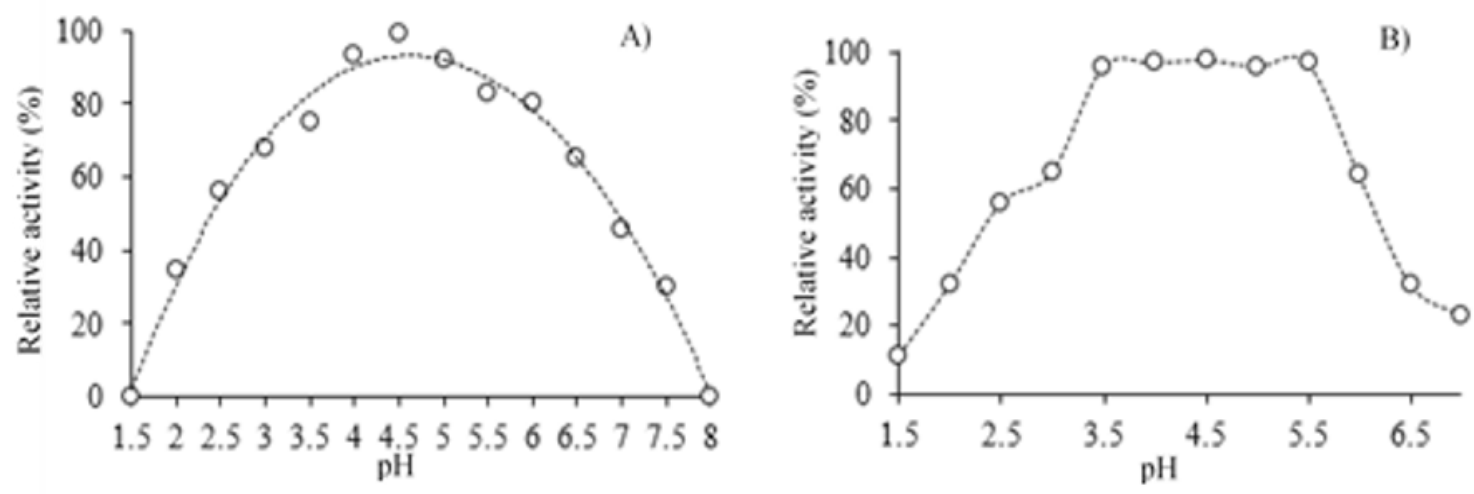


\section{JURNAL BIDDJATI}

http://journal.uinsgd.ac.id/index.php/biodjati
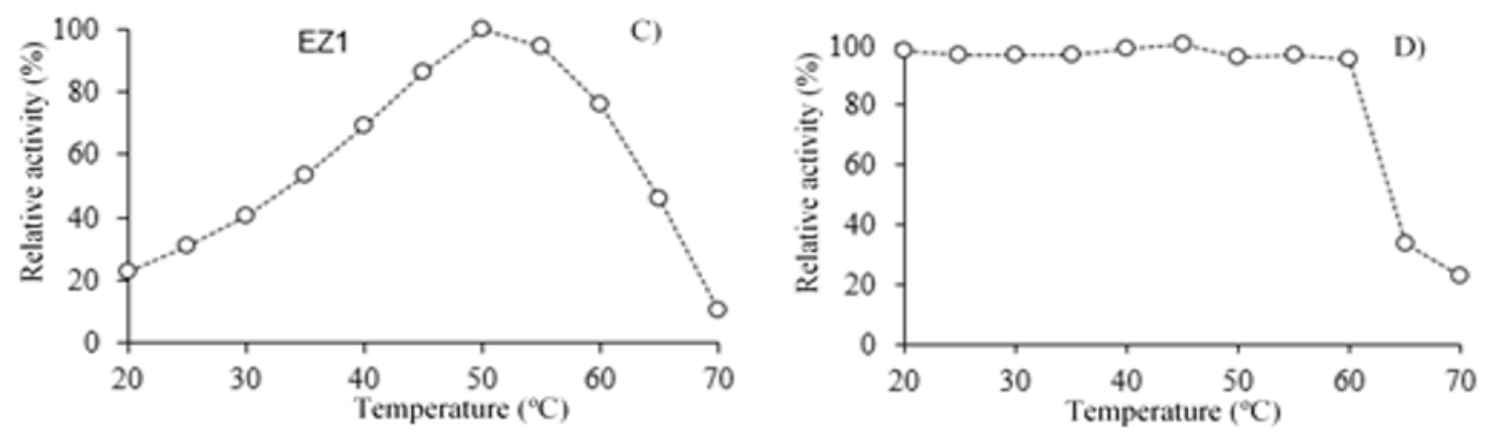

Figure 3. The optimum (A, C) and Stability (B, D) of purified $\alpha$-L-Rhamnosidase activity on temperature and $\mathrm{pH}$.

\section{ACKNOWLEDGMENTS}

This research paper is partially work funded by Direktorat Jenderal Penguatan Riset dan Pengembangan, the Ministry of Research, Technology, and Higher Education of the Republic of Indonesia, 2019.

\section{REFERENCES}

Birgisson, H., Wheat, J. O., Hreggvidsson, G. O., Kristjansson, J. K. \& Mattiasson, B. (2007). Immobilization of a Recombinant Escherichia coli Producing a Thermostable $\alpha$-L-rhamnosidase: Creation of a Bioreactor for Hydrolyses of Naringin. Enzyme and Microbial Technology, 40(5), 1181-1187.

Bokkenheuser, V. D., Shackleton, C. H. \& Winter, J. (1987). Hydrolysis of Dietary Flavonoid Glycosides by Strains of Intestinal Bacteroides from Humans. Biochemical Journal, 248(3), 953-956.

Caldini, C., Bonomi, F., Pifferi, P. G., Lanzarini, G. \& Galante, Y. M. (1994). Kinetic and Immobilization Studies on Fungal Glycosidases for Aroma Enhancement in Wine. Enzyme and Microbial Technology, 16(4), 286-291.

Ding, G., Pei, J., Ge, L., Chen, A., Wang, Z., Muzakhar \& Winarsa
Xiao, W. \& Tang, F. (2017). Enhancing the Thermostability of $\alpha$-L-rhamnosidase from Aspergillus terreus and the Enzymatic Conversion of Rutin to Isoquercitrin by Adding Sorbitol. BMC Biotechnology, 17(1), 1-10.

Ellaiah, P., Prabhakar, T., Ramakrishna, B., Thaer Taleb, A. \& Adinarayana, K. (2004). Production of Lipase by Immobilized Cells of Aspergillus niger. Process Biochemistry, 39(5), 525-528.

Gastón Orrillo, A., Ledesma, P., Delgado, O. D., Spagna, G. \& Breccia, J. D. (2007). Cold-Active $\alpha$-L-rhamnosidase from Psychrotolerant Bacteria Isolated from a Sub-Antarctic Ecosystem. Enzyme and Microbial Technology, 40(2), 236-241.

Habelt, K., \& Pittner, F. (1983). A Rapid Method for the Determination of Naringin, Prunin and Naringenin Applied to the Assay of Naringinase. Analytical Biochemistry, 134(2), 393-397.

Hatzinikolaou, D. G., Macris, J. B., Christakopoulos, P., Kekos, D., Kolisis, F. N. \& Fountoukidis, G. (1996). Production and Partial Characterisation of Extracellular Lipase from Aspergillus niger. Biotechnology Letters, 18(5), 547-552.

Lúcia, F. P. A., da Silva, M. F., de Moura, R. B., Ribeiro Sales, M. \& de Macedo, G. 


\section{JURNAL BIDDJATI}

http://journal.uinsgd.ac.id/index.php/biodjati

R. (2011). Cellulase and Xylanase Production by Aspergillus species. Annals of Microbiology, 61(4), 917-924.

Muzakhar, K., Masruroh, Siswoyo, Winarsa, R. \& Sutoyo. (2017). Sugar-Rich Hydrolysates of Palm Oil Empty Fruit Bunch Production Through Two Step Solid State Fermentations and its Conversion to Ethanol. Advanced Science Letters, 23(3), 2533-2535.

Muzakhar, K., Sutoyo, S. \& Saragih, A. B. (2015). Phosphate Solubilizing Bacteria Adaptive to Vinasse. Journal of Mathematical and Fundamental Sciences, 47(2), 219-225.

Narasimha, G., Reddy, B. R., Dileepkumar, K., Ramanjaneyulu, G., Sridevi, A. \& Devi, P. S. (2015). Saccharification of Pretreated Sawdust by Aspergillus niger Cellulase. 3 Biotech, 5(6), 883-892.

Prakasham, R. S., Subba Rao, C., Sreenivas Rao, R. \& Sarma, P. N. (2007). Enhancement of Acid Amylase Production by an Isolated Aspergillus awamori. Journal of Applied Microbiology, 102(1), 204 211.

Reddy, G. P. K., Narasimha, G., Kumar, K. D., Ramanjaneyulu, G., Ramya, A., Shanti, B. S. \& Rajasekhar, B. (2015). Cellulase Production by Aspergillus niger on Different Natural Lignocellulosic Substrates. International Journal of Current Microbiology and Appied Sciences, 4(4), 835-845.
Vila-Real, H., Alfaia, A. J., Bronze, M. R., Calado, A. R. T. \& Ribeiro, M. H. L. (2011). Enzymatic Synthesis of the Flavone Glucosides, Prunin and Isoquercetin, and the Aglycones, Naringenin and Quercetin, with Selective $\alpha$-L-rhamnosidase and $\beta$-D-glucosidase Activities of Naringinase. Enzyme Research, 2011(1).

Wang, H., Qian, S., Lu, M., Zhang, C., Jin, F. $\&$ Yu, H. (2005). Purification and Characterization of Dioscin- $\alpha$-L-rhamnosidase from Pig Liver. Chemical \& Pharmaceutical Bulletin, 53(8), 911-914.

Yadav, S. (2018). Prunin Production From Orange Peel Naringin Hydrolyzed By a-L-rhamnosidase from Aspergillus flavipus MTCC- 4644. International Journal of Trend in Scientific Research and Development, 2(5), 1271-1278.

Yadav, V., Yadav, P. K., Yadav, S. \& Yadav, K. D. S. (2010). $\alpha$-L-Rhamnosidase: A review. Process Biochemistry, 45(8), 1226-1235.

Yadav, V., Yadav, S., Yadava, S. \& Yadav, K. D. S. (2011). $\alpha$-L-Rhamnosidase from Aspergillus flavus MTCC-9606 Isolated from Lemon Fruit Peel. International Journal of Food Science and Technology, 46(2), 350-357. 